\title{
EFFECTS OF NAPHTHALENE ACETIC ACID (NAA) ON THE PLANT GROWTH AND SUGARS EFFECTS ON THE CUT FLOWERS MOKARA CHARK KUAN ORCHID
}

\author{
EFEITOS DO ÁCIDO NAFTALENO ACÉTICO (NAA) SOBRE O CRESCIMENTO DAS \\ PLANTAS E DE AÇÚCARES SOBRE FLORES CORTADAS DA ORQUÍDEA MOKARA \\ CHARK KUAN
}

\section{Mohammad Moneruzzaman KHANDAKER*; Mohd Zuraini MD RASDI; Nik Nur NAEIMAH; Nashriyah MAT}

School of Agriculture Science \& Biotechnology, Faculty of Bioresources and Food Industry, Universiti Sultan Zainal Abidin, Besut Campus, 22200 Besut, Terengganu, MALAYSIA.*moneruzzaman@unisza.edu.my

\begin{abstract}
A study was carried out to investigate the effects of Naphthalene Acetic Acid (NAA) and sugars on the plants and flowers quality of Mokara Chark Kuan orchid respectively. Parameters were monitored between November 2014 to March 2015, with the application of three concentrations of NAA at 25, 50 and $100 \mathrm{mg} / \mathrm{L}$ in the field. The application of $25 \mathrm{mg} / \mathrm{L}$ NAA significantly increases the plant height, number of roots and total soluble solid content of Mokara Chark Kuan orchid plants. But, there was no significant effect on the leaves number, chlorophyll content and number of flowers. In case of storage experiment, the cut Mokara Chark Kuan flowers were treated with $3 \%$ and $6 \%$ glucose and sucrose. Physiological parameters: fresh weight, water uptake, petal thickness, discoloration and vase life were evaluated. It can be concluded that spraying with $25 \mathrm{mg} / \mathrm{L}$ NAA enhanced the plant growth and development of Mokara Chark Kuan orchid. The study also showed that $6 \%$ sucrose was the best treatment for maintaining the post-harvest quality as well as vase life of cut Mokara Chark Kuan orchid flowers.
\end{abstract}

KEYWORDS: Naphthalene Acetic Acid. Sugar. Sucrose. Glucose. Mokara Chark Kuan orchid. Vase life.

\section{INTRODUCTION}

Orchidaceae comprises the largest family of flowering plants with 25,000 to 35,000 species belonging to 600-800 genera. Orchids are distributed throughout the world except in the coldest areas, and the most numerous in damp equatorial regions. Orchids are very prized for their physiological characteristics, especially in size, shape, color and attractiveness of flowers. In Malaysia, there is a lack of potted orchid hybrids for commercial planting (FADELAH; SAPAWI; KUAN, 2003). Mokara Chark Kuan is a terrestrial hybrid orchid that has a monopodial growth type that allows it to grow upwards from a single point. It grows taller from a single stem in a single upward direction. It does not have a rhizome or pseudo bulb, but adds a few leaves each year as well as flowers that generally come from in-between these leaves (NASHRIYAH et al., 2010). While, Naphthalene Acetic Acid (NAA) is a plant hormone in the auxin family and is an ingredient in many commercial post-harvest horticultural products. It is also a rooting agent and used for vegetative propagation of plants from stem and leaf cuttings (SAIFUDDIN et al., 2009). NAA is applied to the orchid by spraying regularly so that the effect of NAA is shown in the five month application.

Mokara Chark Kuan orchid is a one type of CAM plant which has very low photosynthetic activity. Like other cut flowers, they face vased liferelated problems such as excess water loss, decline in respiratory substrates and sensitivity to ethylene, which hasten senescence and shorten vase life. The influence and effects of sugars and ethylene are two major areas which have been widely studied to tackle the problem of flower quality and vase life of cut flowers. With post-harvest application, the main problems are maintaining the quality and longevity of cut flowers through the loss in carbon source and it can be achieved by the exposure to exogenous sugar and controlling the endogenous ethylene (CHANDRAN et al., 2006). It is significant to investigate the short-term effects of Naphthalene Acetic Acid (NAA) on the orchid plants for producing good quality cut flowers. There were only few experiments that used NAA as an outdoor hormone 
for assessing the growth and quality of orchids. Then for this study, the effect of sugars (sucrose and glucose) on the physical and chemical characteristics of Mokara Chark Kuan flowers are evaluated by focusing on the vase life of the orchid flowers. Commonly the vase life of orchid flower is only 14 to 20 days.

The aims of this study were to assess the effects of Napthalene Acetic Acid (NAA) and sugars on growth of plants and flowers quality of the Mokara Chark Kuan orchid and detemines the effects of sugars on the longevity vase life of Mokara Chark Kuan cut orchid flowers.

\section{MATERIAL AND METHODS}

\section{Plant Materials}

Mokara Chark Kuan orchid plants were collected from a nursery located in Chendering, Terengganu, Malaysia. The plants were kept as faculty living collection at farm of Faculty of Bioresource and Food Industry at Tembila. Mokara Chark Kuan flowers were purchased from a nursery located in Mantin, Negeri Sembilan, Malaysia. After harvest, the flowers were taken to the Plant Physiology Laboratory, Faculty of BioResource and Food Industry, Universiti Sultan Zainal Abidin, Tembila Campus, Besut, Terengganu.

\section{Experimental design}

\section{NAA Application on Plants (Experiment 1)}

This experiment was arranged with a Completely Randomized Design (CRD). There were 4 treatments (Control, $25 \mathrm{mg} / \mathrm{L}, 50 \mathrm{mg} / \mathrm{L}$, and 100 mg/L NAA ) and 4 replications, with 16 total numbers of exper- imental units involving Mokara Chark Kuan species that was put in the nursery for 5 months. These orchids were observed daily and weekly for the effects of Naphthalene Acetic Acid (NAA) on the plants growth parameter such plant height, number of leaves, number of roots, number of flowers, total soluble solids and leaf chlorophyll contents. The treatments and replications were shown below:

\section{Sugars Application on Flowers (Experiment 2)}

This experiment was arranged with a Completely Randomized Design (CRD). There were 5 treatments (Flower + without sugars (control); Flower $+3 \%$ sucrose, Flower $+6 \%$ sucrose, Flower $+3 \%$ glucose and Flower $+6 \%$ glucose) and 5 replications, and with the 25 total numbers of experimental units involving Mokara Chark Kuan flower plants which were collected fresh from the nursery. Then, these flowers were brought into the laboratory and observed daily for the effects of sugars.

\section{Physiological Measurements Plant Height and Number of leaves}

The measurements were done monthly started from after planting in November 2014 until March 2015. Each orchid plant height was recorded in centimetre's. The plant height was measured from the base of the plant on the soil surface to the highest point branch between of leaves. Measuring tape was used to measure the plant height. This parameter was calculated once every month and all the data from each plant were recorded. The method used for counting the number of leaf was by manual counting of observable leaves or called the leaf tip method.

\section{Number of Roots and flowers}

The parameter was calculated once every month and all the data from each plant were recorded. The roots came out from plant's branch were counted as a new roots produced. The flowers were calculated when the orchids have been produced after or in interval of five months. The number of flowers was recorded in each plant.

\section{Fresh Weight, water uptake and petal thickness}

The weight of the flowers was calculated by subtracting the weight of the vials with the solutions and flower with the vials and solution only. The parameter was calculated daily by using the analytical balance. Water uptake was calculated by subtraction of consecutive weights of vial plus the solutions (without the flowers). The parameter was calculated daily by using the analytical balance. Thickness of petal was measured daily by using Micrometer.

\section{Discoloration of petal and vase life of flower} Petal discoloration was observed by observing the petal symptoms by using the following formula ${ }^{3}$ : Petal discolored area $(\%)=\frac{\text { Discolored petal area }}{\text { The total petal area }} \times 100$

The vase life was calculated by counting number of days that flower are remained acceptable. Flower status was observed every day. The flowers that showed senescence symptoms were brown colour. 


\section{Biochemical Measurement}

Total Soluble Solid (TSS) and Leaf Chlorophyll Content

The total soluble solid was measured on the flowers produced by orchid plants after or within five months after planting. TSS was calculated by using Refractometer in \% BRIX. The parameter leaf chlorophyll content was measured once a week for four week by using the SPAD meter. All data were calculated and recorded.

\section{Statistical Analysis}

The experiments on plants and flowers were conducted using a Completely Random Design (CRD) with five replicate and in the field, four treatments and five replicates and five treatments respectively. The analysis of data was done using the variance analysis (ANOVA). Treatment means were compared by Tukey's at $p \leq 0.05$. Due to the significant interaction between the factors significance were determined using regression analysis by SPSS software version 17.0.

\section{RESULTS}

\section{Application of NAA on Orchid Plants} Number of leaves, roots, and flowers
KHANDAKER, M. M. et al.

The physiological studies in different treatment after five months of planting.

In figure 1(a), the application of NAA produced no significant effect on number of leaves produced by Mokara Chark Kuan and the results showed that the highest number of new leaves was observed at $25 \mathrm{mg} / \mathrm{L}$ NAA treatment with a value of $3.2 \pm 1.03$ followed by $50 \mathrm{mg} / \mathrm{L}$ NAA treatment. This result indicated that the number of leaves produced by Mokara Chark Kuan orchid which was not affected significantly by pre-harvest application of NAA among the treatments and control. It means that, application of NAA concentration of orchid plants not affected the leaf production. In figure 1(b), the application of NAA produced the significant effect on number of roots of Mokara Chark Kuan and the results showed that the highest increased number of roots observed at $25 \mathrm{mg} / \mathrm{L}$ NAA treatment with a value of $5.00 \pm 0.58$ followed by 50 and $100 \mathrm{mg} / \mathrm{L}$ NAA treatment respectively. The figure 1(c) show that the application of NAA produced no significant effect on number of flowers produced by Mokara Chark Kuan and the results showed that the highest number of flowers observed at $25 \mathrm{mg} / \mathrm{L}$ NAA treatment with a value of $8.0 \pm 6.44$ followed by 50 and $100 \mathrm{mg} / \mathrm{L}$ NAA treatment.
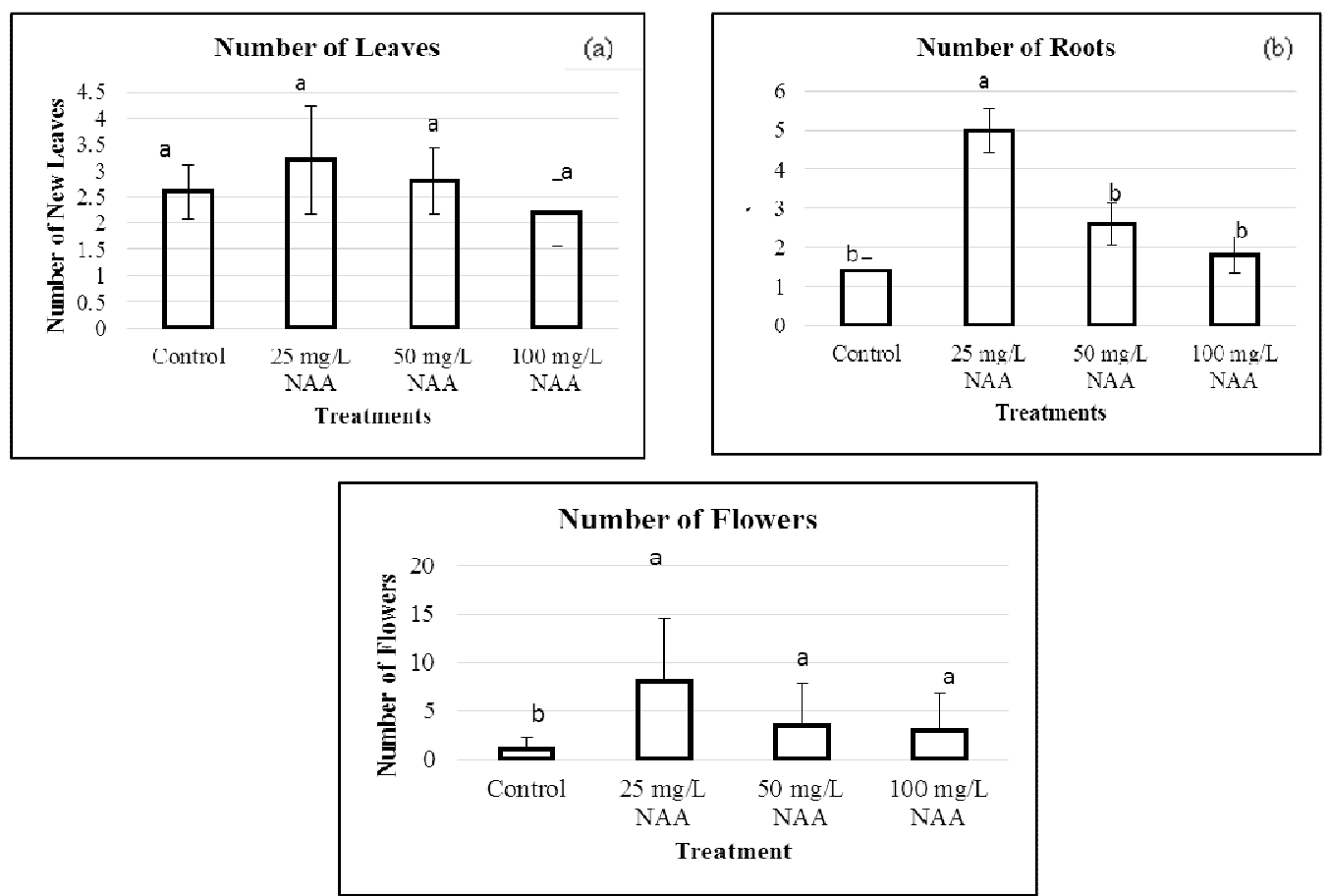

Figure 1. Application of NAA on Orchid Plants Number of leaves, roots, and flowers of Mokara Chark Kuan 


\section{Plant height, leaf chlorophyll content, Total soluble solid (TSS)}

The application of NAA produced the significant effect on plant height of Mokara Chark Kuan and the results showed that the highest increased plant height observed at $25 \mathrm{mg} / \mathrm{L}$ NAA treatment with a value of $4.64 \pm 0.50 \mathrm{~cm}$ followed by 50 and 100 $\mathrm{mg} / \mathrm{L}$ NAA treatment respectively and the lowest increased plant height observed in the control treatment (Table 1). While, there were no significant different from four treatment included control, 25, 50, and $100 \mathrm{mg} / \mathrm{L}$ NAA for chlorophyll content. The highest value of leaf chlorophyll showed was at 50 $\mathrm{mg} / \mathrm{L}$ NAA treatment with $58 \pm 3.08$. It means that, application of NAA concentration to orchid plants not affected the leaf chlorophyll content in each treatment. Besides, the application of NAA produced the significant effect on total soluble solids value of different treatment in Mokara Chark Kuan cut flowers. The results showed that the highest values of total soluble solids was observed at $25 \mathrm{mg} / \mathrm{L} \mathrm{NAA}$ treatment with a value of $3.2 \pm 0.20$ followed by 50 and $100 \mathrm{mg} / \mathrm{L}$ NAA treatment respectively.

\section{Application of Sugars on Orchid Flowers Fresh weight, water uptakes, petal thickness}

In Table 2, the application of sucrose and glucose produced the significant effect on fresh weight of cut Mokara Chark Kuan flowers and the results showed that the highest amount of fresh weight loss observed at $6 \%$ sucrose treatment with a value of $1.88 \pm 0.07 \mathrm{~g}$ followed by $3 \%$ glucose, $6 \%$ glucose and $3 \%$ sucrose treatment respectively. The lowest fresh weight was observed in the control treatment. Fresh weight of all cut Mokara Chark Kuan flower showed increment on early day but decreased continuously towards the end of flower life. The early
KHANDAKER, M. M. et al.

increment may be due to the initial water uptake from the solutions to fulfil the nutrient prerequisite of the cut pollinated flowers. After that, water uptake was no longer effectual as the fresh weight began to drop. Fresh weight continued to decrease throughout the experiment in the control flowers. While, the application of sucrose and glucose produced the significant effect on water uptake of cut Mokara Chark Kuan flowers and the results showed that the highest amount of water uptake loss observed at $6 \%$ sucrose treatment with a value of $1.29 \pm 0.05 \mathrm{~g}$ followed by $3 \%$ glucose, $6 \%$ glucose and $3 \%$ sucrose treatment respectively. The lowest water uptake was observed in the control treatment. The results showed that the highest value of petal thickness maintained until wilted observed at $6 \%$ sucrose treatment with a value of $22.36 \pm 1.99 \mathrm{~mm}$ followed by $3 \%$ glucose, $6 \%$ glucose and $3 \%$ sucrose treatment respectively. The lowest was value observed in the control treatment. The results showed that the highest days until wilt be observed was achieved at $6 \%$ sucrose treatment with a value of 21 \pm 1.0 days followed by $3 \%$ glucose, $6 \%$ glucose and $3 \%$ sucrose treatment respectively. The lowest days was observed in the control treatment. On top of that, the application of sucrose and glucose produced the significant effect on petal thickness of cut Mokara Chark Kuan flowers. The results showed that the highest value of petal thickness maintained until wilted was observed at $6 \%$ sucrose treatment with a value of $22.36 \pm 1.99 \mathrm{~mm}$ followed by $3 \%$ glucose, 6 $\%$ glucose and $3 \%$ sucrose treatment respectively. The lowest value was observed in the control treatment. The petal thickness decreased with time was observed for cut Mokara Chark Kuan flowers held in all treatments. 
Table 1. Multiple comparison of plant height, leaf chloropyll content and total soluble solid for application of NAA on orchid plants.

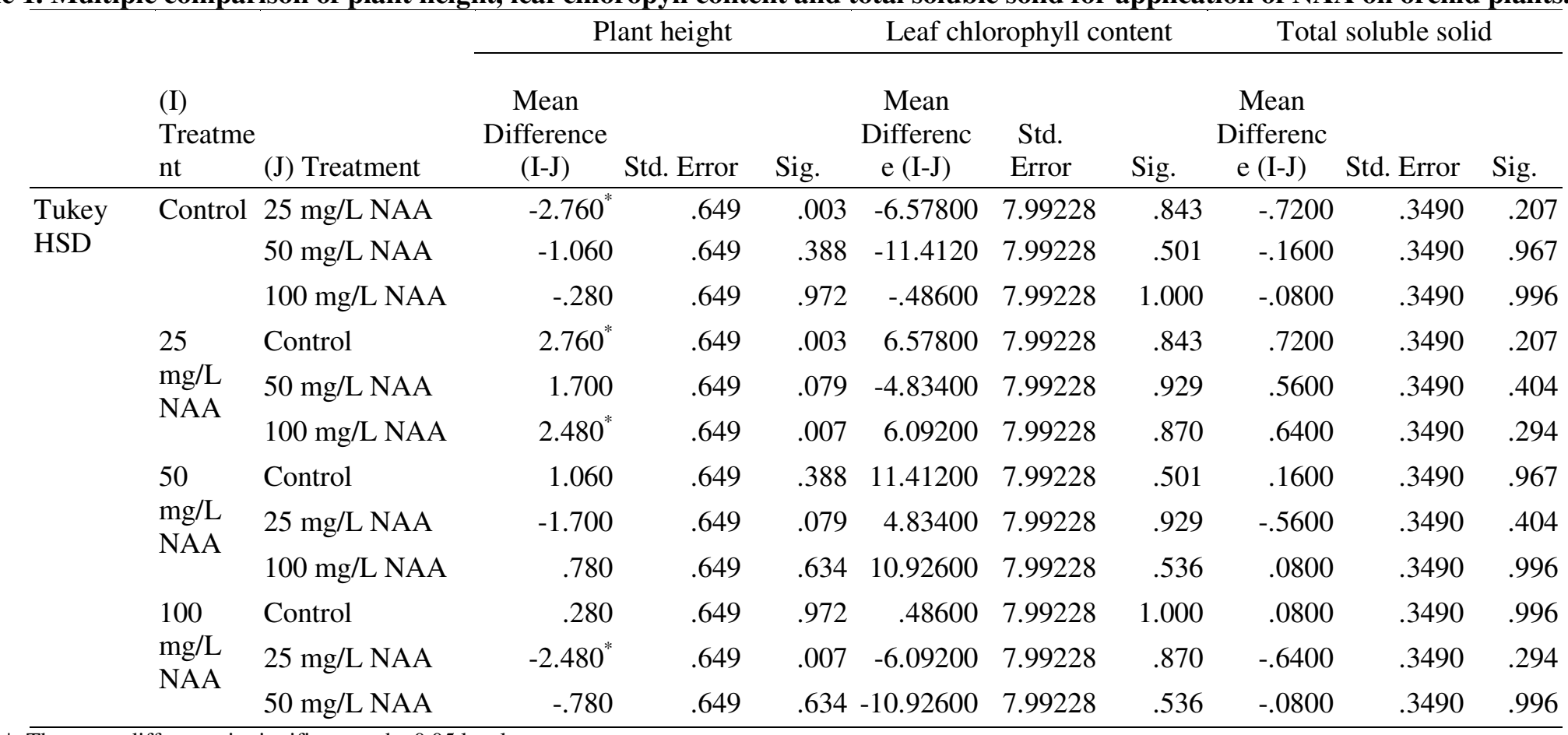

*. The mean difference is significant at the 0.05 level. 
Table 2. Multiple comparison of fresh weight, water uptake and petal thickness for application of sugars on orchid flowers.

\begin{tabular}{|c|c|c|c|c|c|c|c|c|c|c|}
\hline & \multirow[b]{2}{*}{$\begin{array}{l}\text { (I) } \\
\text { Treatment }\end{array}$} & \multirow[b]{2}{*}{$\begin{array}{l}(\mathrm{J}) \\
\text { Treatment }\end{array}$} & \multicolumn{2}{|c|}{ Fresh weight } & \multicolumn{3}{|c|}{ Water uptake } & \multicolumn{3}{|c|}{ Petal thickness } \\
\hline & & & $\begin{array}{c}\text { Mean } \\
\text { Difference (I-J) }\end{array}$ & Std. Error & $\begin{array}{cc} & \text { Mean } \\
& \text { Difference (I- } \\
\text { Sig. } & \text { J) }\end{array}$ & Std. Error & Sig. & $\begin{array}{c}\text { Mean } \\
\text { Difference } \\
(\mathrm{I}-\mathrm{J})\end{array}$ & $\begin{array}{l}\text { Std. } \\
\text { Error }\end{array}$ & Sig. \\
\hline \multirow{20}{*}{$\begin{array}{l}\text { lukey } \\
\text { HSD }\end{array}$} & Control & $3 \%$ Sucrose & $-.6322800^{*}$ & .0947756 & $.000-.4314600^{*}$ & .0964564 & .002 & -1.92000 & 1.85170 & .835 \\
\hline & & $6 \%$ Sucrose & $-1.4800400^{*}$ & .0947756 & $.000-.9468800 *$ & .0964564 & .000 & $-8.78000^{*}$ & 1.85170 & .001 \\
\hline & & $3 \%$ Glucose & $-1.2776000^{*}$ & .0947756 & $.000-.7726800 *$ & .0964564 & .000 & $-5.66000^{*}$ & 1.85170 & .044 \\
\hline & & $6 \%$ Glucose & $-.6879000^{*}$ & .0947756 & $.000-.4845000 *$ & .0964564 & .001 & -4.50000 & 1.85170 & .148 \\
\hline & $3 \%$ Sucrose & Control & $.6322800^{*}$ & .0947756 & $.000 .4314600^{*}$ & .0964564 & .002 & 1.92000 & 1.85170 & .835 \\
\hline & & $6 \%$ Sucrose & $-.8477600^{*}$ & .0947756 & $.000-.5154200 *$ & .0964564 & .000 & $-6.86000^{*}$ & 1.85170 & .011 \\
\hline & & $3 \%$ Glucose & $-.6453200^{*}$ & .0947756 & $.000-.3412200 *$ & .0964564 & .016 & -3.74000 & 1.85170 & .293 \\
\hline & & $6 \%$ Glucose & -.0556200 & .0947756 & $.976-.0530400$ & .0964564 & .981 & -2.58000 & 1.85170 & .639 \\
\hline & $6 \%$ Sucrose & Control & $1.4800400^{*}$ & .0947756 & $.000 .9468800^{*}$ & .0964564 & .000 & $8.78000^{*}$ & 1.85170 & .001 \\
\hline & & $3 \%$ Sucrose & $.8477600^{*}$ & .0947756 & $.000 .5154200^{*}$ & .0964564 & .000 & $6.86000^{*}$ & 1.85170 & .011 \\
\hline & & $3 \%$ Glucose & .2024400 & .0947756 & .244 .1742000 & .0964564 & .398 & 3.12000 & 1.85170 & .465 \\
\hline & & $6 \%$ Glucose & $.7921400^{*}$ & .0947756 & $.000 .4623800^{*}$ & .0964564 & .001 & 4.28000 & 1.85170 & .182 \\
\hline & $3 \%$ Glucose & Control & $1.2776000^{*}$ & .0947756 & $.000 .7726800^{*}$ & .0964564 & .000 & $5.66000^{*}$ & 1.85170 & .044 \\
\hline & & $3 \%$ Sucrose & $.6453200^{*}$ & .0947756 & $.000 .3412200^{*}$ & .0964564 & .016 & 3.74000 & 1.85170 & .293 \\
\hline & & $6 \%$ Sucrose & -.2024400 & .0947756 & $.244-.1742000$ & .0964564 & .398 & -3.12000 & 1.85170 & .465 \\
\hline & & $6 \%$ Glucose & $.5897000^{*}$ & .0947756 & .000 .2881800 & .0964564 & .050 & 1.16000 & 1.85170 & .969 \\
\hline & $6 \%$ Glucose & Control & $.6879000^{*}$ & .0947756 & $.000 .4845000^{*}$ & .0964564 & .001 & 4.50000 & 1.85170 & .148 \\
\hline & & $3 \%$ Sucrose & .0556200 & .0947756 & .976 .0530400 & .0964564 & .981 & 2.58000 & 1.85170 & .639 \\
\hline & & $6 \%$ Sucrose & $-.7921400^{*}$ & .0947756 & $.000-.4623800^{*}$ & .0964564 & .001 & -4.28000 & 1.85170 & .182 \\
\hline & & $3 \%$ Glucose & $-.5897000^{*}$ & .0947756 & $.000-.2881800$ & .0964564 & .050 & -1.16000 & 1.85170 & .969 \\
\hline
\end{tabular}

*. The mean difference is significant at the 0.05 level. 


\section{Vase life}

In figure 2, the application of sucrose and glucose produced the significant effect on vase life of cut Mokara Chark Kuan flowers.

The results showed that The highest number of days until wilt be observed was achieved at $6 \%$ sucrose treatment with a value of $21 \pm 1.0$ days followed by $3 \%$ glucose, $6 \%$ glucose and 3 $\%$ sucrose treatment respectively. The lowest days observed was in the control treatment.

\section{Discoloration of petal}

The discolouration of petals in cut Mokara Chark Kuan flowers held in different treatment solutions it is showing in Figure 3. The discolouration of petals results were significant different between $6 \%$ sucrose to control and 3\% sucrose. The colours changes for cut Mokara Chark Kuan flowers treated with $6 \%$ sucrose and $3 \%$ glucose started to decrease gradually from days $4^{\text {th }}$ to days $12^{\text {nd }}$ respectively compared to the $3 \%$ sucrose which started to decrease sharply on days $12^{\text {nd }}$. It was observed from the colour changes, that there was flower discolouration from the early days after transfer to vase solution.

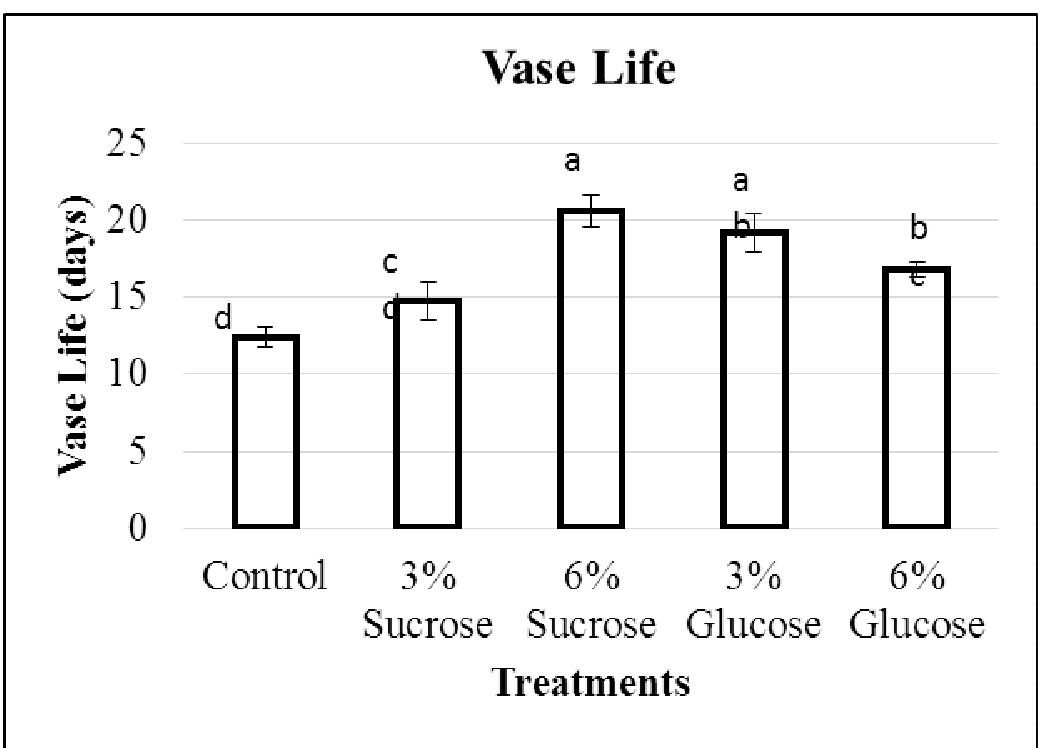

Figure 2. The effect of application of sugar on vase life' orchid flowers

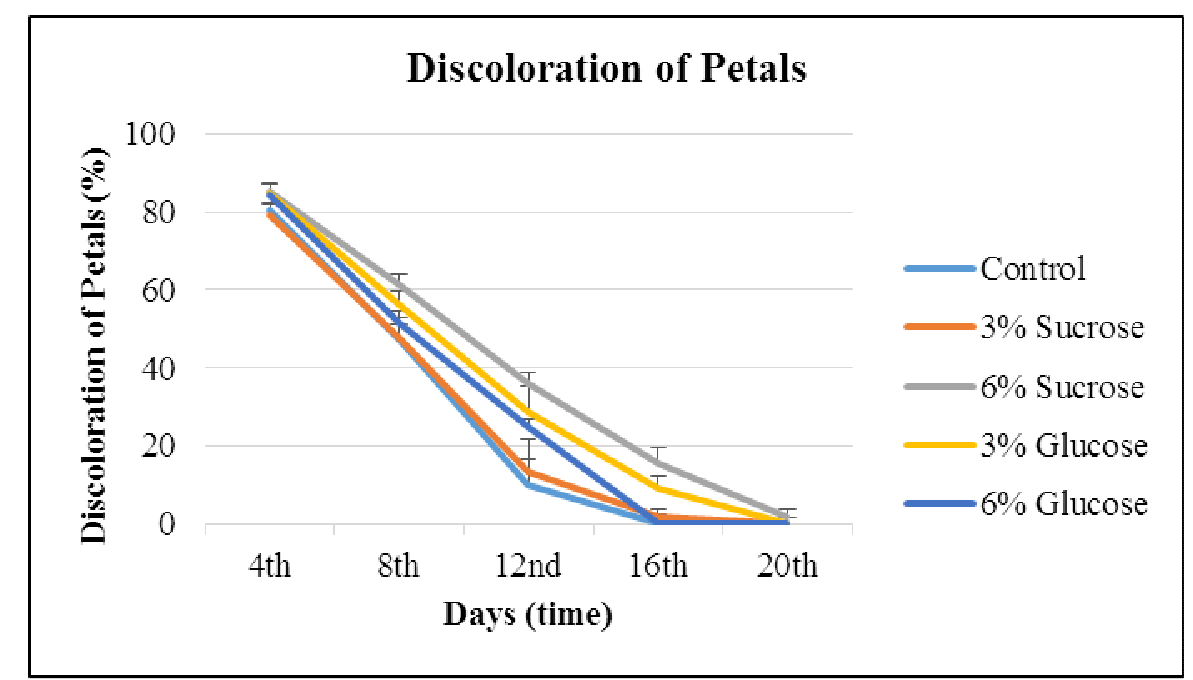

Figure 3. The effect of discoloration of petals on application of sugar on orchid flowers. 


\section{DISCUSSION}

\section{Application of NAA on Orchid Plants}

This results are in agreement with the findings of Dimitrios et al. (2008), which stated that function of NAA are rooting agent and used for vegetative propagation of plants from stem and leaf cutting. NAA treatments significantly increased the plant height. It important to note that increased plant height increased the production of flowers. Agusti et al. (1996), mentioned that NAA effect might be due enhancement of cell enlargement, not cell division. From our results, it was observed that leaf chlorophyll content of orchid did not affected significantly with the application of NAA treatments. It was also observed that NAA treatments significantly increased the TSS content of orchid flowers. Saifuddin et al. (2009) also reported that NAA treatment significantly increased the TSS content in bougainvillea flowers and improves the flower quality. Moneruzzaman et al. (2010a), recommended that sucrose and kinetin hormone can be applied to improve post-harvest life of bougainvillea flowers. It has been reported that removal of young leaf and kinetin application enhance the inflorescence development and improve the quality of flower in bougainvillea plants (MONERUZZAMAN et al. 2010b). Results showed that NAA treatment significantly increased the flowers number and quality of orchid flower. Similar findings are reported by Moneruzzaman et al. (2012), who stated that growth regulator triacontanol application promote the flowering and flower quality of bougainvillea flower. Our results also showed that NAA application significantly improved the flower quality of Mokara Chark Kuan and thus can extend the vase life of this orchid flower.

\section{Application of Sugars on Orchid Flowers}

The results found in our study supported with the finding of Chandran et. al. (2006) which reported that when cut flowers are treated with sugars there is an increase in the pool of respirable substrates, delay the onset of hydrolysis of structural components and improve water balance. Water uptake increased in the flowers during the initial period probably due to the water potential gradient in the early days of the experiment. It is well known that vase life depends to a great extent on the maintenance of a proper water balance in the flower. Increased turgidity can contribute to petal thickness. It has been reported that ethylene induced by pollination signal specific enzymes to cause cell wall rupture due to hydrolytic activity (PANAVAS;
REID; RUBINSTEIN, (1998). Sucrose is preferred presumably because it is a major metabolite in plant cells and is readily metabolized. Then, bacteria growth clogs the xylem vessels and inhibits water transport to maintain the freshness. This increased the senescence of Mokara Chark Kuan flowers in vase solution.

\section{Petal thickness}

The results showed that the petal thickness decreased with time for cut Mokara Chark Kuan flowers held in all treatments. The reason for this was probably the reduction in the ability to uptake water. It had been reported that the tightly packed circulating cells in the cortex of daily petals assume a reticulate pattern due to the formation of irregular cell shape and the decrease of cell to cell attachments during water loss (NICHOLS, 1983; HO; NICHOLS, 1977). Sugar treatment significantly increased the shelf life of Mokara chark kuan. Vase life of Mokara Chark Kuan was dependent on the amounts of sugars which was effecting delay period of senescence. Keeping flowers in vase solutions containing sucrose has been shown to extend their vase life (Coorts, 1973). Supplying cut flowers with exogenous sugar maintain the pool of dry matter and respirable substrates, especially in petals, thus promoting respiration and extending longevity (ROGERS, 1973). Aarts (1957) suggested that exogenous sucrose in some way maintains the structure and semi-permeability of the plasma membrane.

\section{Vase life}

The post-harvest life of a flower is strongly dependent on the carbohydrate status and the acceptable amounts of metabolic sugars are factors that affect the rate of senescence (Nashriyah et al., 2010). Keeping flowers in vase preservative solutions containing sucrose have been shown to extend their vase life (HO; NICHOLS, 1977). Chandran et al., (2008) reported that the vase life was can be prolonged for up to 6 folds compared to that of the control. Treatments with $4 \%$ glucose and $2 \%$ sucrose also managed to extend the longevity of the pollinated flowers from 2 to 5 days. Supplying cut flowers with exogenous sugar maintained the pool of dry matter and respirable substrates, especially in petals, thus promoting respiration and extending longevity (COORTS, 1973; ROGERS, 1973). Aarst (1957) reported that exogenous sucrose in some ways maintains the structure and semipermeability of the plasma membrane. It was determined that sucrose dominated the effect of abscisic acid in promoting the senescence of roses 
(BOROCHOV; MAYAK; HALEVY, 1976). Moreover, treatment of cut flowers with sucrose is found to be beneficial in delaying senescence processes (YAKIMOVA; ATANASSOVA; KAPCHINA-TOTEVA, 1997). Exogenous supply of sugars delays wilting in many flowers and this effect is due to maintenance in starch and sugar levels in cut flowers (RATTANAWISALANON; KETSA; VAN-DOOR, 2003).

Lee et al. (2005) opined that the term vase life should represent the potential useful longevity of the flowers at the final consumer's home. The short vase life of roses is often related to water stress characterized by incomplete bud opening, rapid loss of fresh weight and water deficit and poor maintenance of turgidity (NASHRIYAH et al. 2010). The importance of water, sugar and various other chemical preservatives to promote the keeping quality of cut flowers has been reported by several workers (HAN, 1997; HUNTER et al., 2004). Cut flowers are graded according to the length of their stem. The longer stem cut flowers have longer vase life, which may be due to higher carbohydrate reserve when compared to the shorter stem, which enables the maintenance of dry matter and respirable substrates, especially in the petals which helps in extending the keeping quality (COORTS, 1973). It was assumed that the vase life is ceased when any of the yellowing symptoms appear at greater than 30 percent (ALMASI et al. 2013). Bacterial growth is a major threat to maintain the vase life of orchid in sugar vase solution. The main disadvantages of sugars in the vase solution is the promotion of bacterial growth when not accompanied by an adequate antimicrobial agent and it may therefore clog the xylem vessels and inhibit the uptake of both water and dissolved sugars. This effect on the effectiveness of sugars as a continuous energy supply for cut flowers is retarded due to the absence of an antimicrobial agent causing stem blockage (Nashriyah et al. 2010). Physiological and morphological responses such as wilting or a bent neck are caused by bacteria, which lead to a decrease in the vase life of rose cut flowers (LEIV; HANS, 2005).

\section{Petal discoloration}

Petal discoloration was the highest in control then the sugar treatment. Petal discoloration increased gradually with the advancement of time. As a result, there was a significant decrease in the discolouration of Mokara Chark Kuan flowers during senescence as their petals became more translucent. This occurrence can be ascribed to the breakdown of pigments such as carotene and anthocyanin which are well documented in Dendrobium and other orchids (ARDITI; PRIDGEON, 1997).

Cut flowers suffer from energy deficiency and are susceptible to different stresses. In these situations, cells require more sugar to fulfil energy needs and carbon sources for the defensive response to stresses (KOIZUKA; TANAKA; MOROCHASHI, 1995). In addition, the ethylene gas decreases the longevity of cut flowers causing them to wilt rapidly (Nair; Tung, 1980). It is not only found in the atmosphere as a product of incomplete combustion, but is also produced by aging plant tissues such as ripening fruit and senescing flowers (Abeles, 1973). Orchids, such as the Oncidium Gower Ramsey are among the flowers that suffer from the post pollination effects as signalled out by endogenous ethylene which eventually results in genetic and physiological changes of the flower. These changes are very similar to that of natural senescence involving weight loss, water loss and discoloration which eventually leads to death.

\section{CONCLUSIONS}

The tested concentrations of NAA, particularly $25 \mathrm{mg} / \mathrm{L}$ can improve the growth, plant height, number of roots and total soluble solids (TSS) content of Mokara Chark Kuan orchid plants.

The study about the application of sugars (sucrose and glucose) on the Mokara Chark Kuan orchid flowers concluded that the sugars, particularly $6 \%$ sucrose can maintaining the most of the parameters included fresh weight, water uptake and petal thickness of cut Mokara Chark Kuan flowers. Therefore, by applying this treatment, the longevity of flowers would be increased and this factor is very important for floriculture in Malaysia especially related to the export and import of flowers.

\section{ACKNOWLEDGEMENTS}

We greatly thank to Universiti Sultan Zainal Abidin and Ministry of Education (FRGS/2/2014/SG03/ UNISZA/02/1) for the writing and publication support. 
RESUMO: Um estudo foi realizado para investigar os efeitos do ácido naftaleno ácido acético (NAA) no crescimento de e açúcares no plantas e na qualidade de flores da orquídea Mokara Chark Kuan . Os parâmetros foram monitorados entre novembro de 2014 e março 2015, com a aplicação de três concentrações de ANA em 25,50 e 100 mg / L sob condições de campo. A aplicação de $25 \mathrm{mg} / \mathrm{L}$ de ANA aumentou significativamente a altura da planta, o número de raízes e o teor de sólidos solúveis totais de plantas de orquídeas Mokara Chark Kuan. Todavia, não houve nenhum efeito significativo sobre o número de folhas, o teor de clorofila e o número de flores. No caso do experimento de armazenamento, flores cortadas de Mokara Chark Kuan foram tratadas com 3\% e 6\% de glicose e de sacarose. Os parâmetros fisiológicos: peso fresco, absorção de água, espessura pétala, descoloração e vida de vaso foram avaliados. Pode concluir-se que a pulverização com $25 \mathrm{mg} / \mathrm{L}$ de NAA aumentou o crescimento e o desenvolvimento das plantas de orquídea Mokara Chark Kuan. O estudo também mostrou que 6\% de sacarose foi o melhor tratamento para a manutenção da qualidade pós-colheita, bem como vida de vaso em flores de corte da orquídea Mokara Chark Kuan .

Vida de vaso.

PALAVRAS-CHAVE: Ácido naftaleno acético. Açúcar. Sacarose. Glicose. Orquídea Mokara Chark Kuan.

\section{REFERENCES}

AARTS, J. F. T. On the keep ability of cut flowers. Meded Landbouwhogesh Wageningen, v. 57, p. 1-62. 1957. Available in: http://tjeas.com/wp-content/uploads/2013/07/1120-1123.pdf

ABELES F. B. Ethylene in plant biology. Academic Press New York, 1973. 9 p.

AGUSTI, M.; ALMELA, V.; ZARAGOZA, S.; PRIMO-MILLO, E.; EL-OTMANI, M. Recent findings on the mechanisms of action of the synthetic auxins used to improve fruit size of Citrus. Proceeding International Society of Citriculture, v. 2, n. 2, p. 922-928. 1996. Available in: http://www.crec.ifas.ufl.edu/academics/classes/ hos6546/materials/ ISC_2_1996_922-928.

ALMASI, P.; TENGKU, M.; MOHAMED, M.; AHMAD, S. H.; KADIR, J.; HASSAN, F. Postharvest responses of six cut Mokara spp. hybrids to exogenous ethylene. Australian Journal of Crop Science, v. 7, n. 7, p. 894-899. 2013. Available in: http://www.sjau.ac.ir/content

ARDITTI, J.; PRIDGEON, A. M. Orchid Biology: Reviews and Perspectives. Kluwer Academic Publishers, Netherlands, 1997, 394p. Available in: http://devcell.bio.uci.edu/faculty/1287-2/

BOROCHOV, A.; MAYAK, S.; HALEVY, A. H. Combined effects of acid and sucrose on growth and senescence of rose flowers. Plant Physiology, v. 36, n. 3, p. 221-224. 1976. Available in: shodhganga.inflibnet.ac.in/bitstream/10603/75532/11/11_references

CHANDRAN, S.; TOH, C. L.; ZULIANA, R.; YIP, Y. K.; NAIR, H.; BOYCE, A. N. Effects of sugars and Aminooxyacetic acid on the longevity of pollinated Dendrobium (Heang Beauty) flowers. Journal of Applied Horticulture, v. 8, n. 2, p. 117-120. 2006. Available in: http://horticultureresearch.net/Page

COORTS G.D. Internal metabolic changes in cut flowers. Hort Science, v. 8, n. 3, p.195. 1973. Available in: journal.ashspublications.org/content/117/3/442.

DIMITRIOS, P. N.; TZANETOS, I. C.; GEORGIA, P. N.; NIKOS, P. A portable sensor for the rapid detection of naphthalene acetic acid in fruits and vegetables using stabilizer in air lipid films with incorporated auxinbinding protein 1 receptor. Talanta, v. 77, n. 2, p. 786-792. 2008. Available in: iosrjournals.org/iosrjavs/papers/vol7-issue1/Version-1/B07110812.

FADELAH, A. A.; SAPAWI, C.; KUAN, C. Preliminary results from varietal improvement of Mokara orchid through mutagenesis. Journal of Tropical Agriculture and Food Scence, v. 31, n. 1, p. 25-28. 2003. Available in: http://www.ajol.info/index.php/ijotafs 
HAN, S. S. Preventing postproduction leaf yellowing in Easter lily. Journal of American Society of Horticultural Science, v. 122, n. 6, p. 869-872. 1997. Available in: https://stockbridge.cns.umass.edu/susanhan

HO, L.; NICHOLS, R. Translocation of 14C-sucrose in relation to changes in carbohydrate content in rose corollas cut at different stages of development. Annual Botany, v. 41, n. 1, p. 227-242. 1977. Available in: serialsjournals.com/serialjournalmanager/pdf/1435319125.

HUNTER, D. A.; YI, M.; XU, X.; RIED, M. S. Role of ethylene in perianth senescence of daffodil (Narcissus pseudonarcissus L. 'Dutch Master'). Postharvest Biology and Technology, v. 32, n. 3, p. 269-280. 2004. Available in: https://espace.library.uq.edu.au/view/.../Chamani_et_al_20.p.

KOIZUKA, N.; TANAKA, Y.; MOROCHASHI, Y. Expression of $\alpha$-amylase in respond to wounding in mungbean. Planta, v. 195, n, 14, p. 530-534. 1995. Available in: www.horizonpress.com/cimb/v/v11/81.

LEE, Y.; GOH, C.; WONG, S.; TAN, W. Breeding vandaceous orchids for commercial cut-flowers in Singapore: an overview. Euphytica, v. 89, n. 2, p. 235-241. 1996. Available in: serials.unibo.it/cgiser/start/en/spogli/ds-s.tcl?authors $=\% 22+$ Wong $\% 2 \mathrm{C}$

LEIV, M. M.; HANS, R. G. Effect of air humidity variation on powdery mildew and keeping quality of cut roses. Scientia Horticulturae, v. 140, n. 1, p. 49-55. 2005. Available in: biozoojournals.ro/swjhbe/v2n2/05.swjhbe.v2n2.Abbasi.pdf

MONERUZZAMAN, K. M.; HOSSAIN, A. B. M. S.; SAIFUDDIN, M.; IMDADUL, H.; NORMANIZA, O.; AMRU N.B. Effects of sucrose and kinetin on the quality and vase life of Bougainvillea glabra Var. Elizabeth angus bracts at different temperature. Australian Journal of Crop Science, v. 4, n. 7, p. 474-479. 2010. Available in: www.cropj.com/khandaker2_4_7_2010_474_479.

MONERUZZAMAN, K. M.; HOSSAIN, A. B. M. S.; NORMANIZA, O.; SAIFUDIN, M.; SANI, W.; AMRU, N. B. Effects of removal of young leaves and cytokinin on inflorescence development and bract enlargement in Bougainvilea glabra var. "Elizabeth Angus". Australian Journal of Crop Science, v. 4, n. 7, p. 467-473. 2010. Available in: www.cropj.com/khandaker1_4_7_2010_467_473.

MONERUZZAMAN, K. M.; FARUQ, G.; MOTIOR, M. R.; SOFIAN-AZIRUN, M.; BOYCE, A. N. The Influence of 1-Triacontanol on the Growth, Flowering and Quality of Potted Bougainvillea Plants (Bougainvillea glabra var. Elizabeth angus) Under Natural Conditions. The Scientific World Journal, v. 2013, n. 5, p. 12. 2013. Available in: www.hindawi.com/journals/tswj/2013/308651/

NAIR, H.; TUNG, H. F. Investigations of cut flower longevity of Oncidium flexuosum x Oncidium sphacelatum. Proc. Third ASEAN Orchid Congress: Ministry of Agric., Kuala Lumpur, Malaysia, p. 8595. 1980. Available in: www.postharvestum.org/home/about-us/prof-helen

NASHRIYAH, M.; SHAMSIAH, A. R.; SALMAH, M.; MISMAN, S.; AKMAM, M. N. M.; JAMALIAH, M. Y.; MAZLEHA, M. Growth and Mineral Content of Mokara chark kuan Pink Orchid as Affected by Allelopathic Lantana camara Weed. International Journal of Biological, Biomolecular, Agricultural, Food and Biotechnological Engineering, v. 4, n. 1, p. 595-599. 2010. Available in: waset.org/.../growth-andmineral-content-of-mokara-chark-kuan-pink-orchid-as-affec

NICHOLS, R.; BUFLER, G.; MOR, Y.; FUJINO, D. W.; REID, M. S. Changes in ethylene production and ACC content of pollinated carnation flowers. Journal of Plant Growth Regulatory, v. 2: n. 1, p. 1-8. 1983. Available in: link.springer.com/article/10.1007\%2FBF02042229 
PANAVAS, T.; REID, P. D.; RUBINSTEIN, B. Programmed cell death of daylily petals: activities of wallbased enzymes and effects of heat shock. Plant Physiology and Biochemistry, v. 36, n. 5, p. 379-388. 1998. Available in: www.ncbi.nlm.nih.gov/.../PMC58968/

RATTANAWISALANON, C.; KETSA, S.; VAN DOORN, W. G. Effect of Aminooxyacetic acid and sugars on the vase life of Dendrobium flowers. Postharvest Biology and Technology, v. 29, n. 1, p. 93-100. 2003. Available in: www.sciencedirect.com/science/article/pii/S0925521402002429

ROGERS, M. An historical and critical review of postharvest physiology research on cut flowers. Hort Science, v. 8, n. 3, p. 189-194. 1973. Available in: https://www.researchgate.net/../284088497

SAIFUDDIN M.; HOSSAIN A.B.M.; NORMANIZA O.; BOYCE A.; \& MONERUZZAMAN K. The Effect of NAA and GA3 in prolonging bract longevity and delaying Discoloration of Bunga Kertas. Biotechnology, v. 8, n. 3, p. 343-350. 2009. Available in: scialert.net/fulltext/?doi=biotech.2009.343.350

YAKIMOVA, E.; ATANASSOVA, B. B.; KAPCHINA-TOTEVA, V. Longevity and some metabolic events in post-harvest Spray carnation flowers. Bulgarian Journal of Plant Physiology, v. 23, n. 3, p.57-65. 1997. Available in: www.bio21.bas.bg/ipp/gapbfiles/v-23/97_3-4_57-65. 